\title{
Online Distance Learning with Cataloging Mentors: The Mentor's Viewpoint
}

\section{Kate Harcourt \& Susan M. Neumeister}

To cite this article: Kate Harcourt \& Susan M. Neumeister (2002) Online Distance Learning with Cataloging Mentors: The Mentor's Viewpoint, Cataloging \& Classification Quarterly, 34:3, 293-298

To link to this article: https://doi.org/10.1300/J104v34n03_03

央 Published online: 23 Oct 2009.

Submit your article to this journal $₫$

山 Article views: 52

Q View related articles $๘$

Citing articles: 1 View citing articles 


\title{
Online Distance Learning with Cataloging Mentors: The Mentor's Viewpoint
}

\author{
Kate Harcourt \\ Susan M. Neumeister
}

\begin{abstract}
SUMMARY. Cataloging experts from across the United States were asked to critique assignments from students enrolled in Professor Gertrude Koh's classes at the Graduate School of Library and Information Science at the Dominican University in River Forest, Illinois through the use of an Internet bulletin board (WebBoard ${ }^{\mathrm{TM}}$, O'Reilly \& Associates, Inc.). This paper examines the mentors' perspective on teaching cataloging and their experience in teaching future colleagues via the WebBoard. [Article copies available for a fee from The Haworth Document Delivery Service: 1-800-HAWORTH. E-mail address: <getinfo@haworthpressinc.com> Website: <http://www.Haworth Press.com> ( ) 2002 by The Haworth Press, Inc. All rights reserved.]
\end{abstract}

KEYWORDS. Mentoring, distance education, cataloging education, Internet resource cataloging

\section{INTRODUCTION AND BACKGROUND}

This paper reports on the experiences of the authors Sue Neumeister and Kate Harcourt, who have been mentoring students in Professor Gertrude

Kate Harcourt is Assistant Head, Original and Special Materials Cataloging, Butler Library, Columbia University. Susan M. Neumeister is affiliated with the Acquisitions Department, University at Buffalo Libraries.

[Haworth co-indexing entry note]: “Online Distance Learning with Cataloging Mentors: The Mentor's Viewpoint." Harcourt, Kate, and Susan M. Neumeister. Co-published simultaneously in Cataloging \& Classification Quarterly (The Haworth Information Press, an imprint of The Haworth Press, Inc.) Vol. 34, No. 3, 2002, pp. 293-298; and: Education for Cataloging and the Organization of Information: Pitfalls and the Pendulum (ed: Janet Swan Hill) The Haworth Information Press, an imprint of The Haworth Press, Inc., 2002, pp. 293-298. Single or multiple copies of this article are available for a fee from The Haworth Document Delivery Service [1-800-HAWORTH, 9:00 a.m. - 5:00 p.m. (EST). E-mail address: getinfo@haworthpressinc.com]. 
Koh's cataloging classes since the summers of 1998 and 2000 respectively. Initially called "Internet Resources Cataloging and Access Management," the class has evolved with the changing times and is currently called: "Metadata for Internet Resources." From the beginning, the experience and guidance of experienced professional electronic resource catalogers has proved to be a valuable addition to the classroom.

The Dominican University's WebBoard was used as the tool for online conferencing for the class to enable mentors and students to share information quickly and easily. We were able to post messages directly to the WebBoard conference and to attach files to our messages. Although neither of us had used a WebBoard before, after we had read an overview of the WebBoard structure that Professor Koh sent through email to all mentors, we found that navigating through the WebBoard was quite simple, and after brief examination, each "button" link was found to be essentially self-explanatory. Although first time posting can be intimidating, some of the stress was removed by the WebBoard's ability to allow re-reading messages and spell checking responses before sending and posting them.

Before each semester began, Professor Koh would inform the mentors as to what would be involved in the current distance learning project. Typically a project would include critiquing a few catalog records during a one-week period, utilizing the distance education method (WebBoard). She would provide the starting and ending dates she had set for the project and asked the mentors to inform her if they were available for another week afterward in case students had additional questions.

Individual students chose mentors based on biographies sent to Professor Koh. Prior to the start of each semester, Professor Koh would update these biographies, by asking the mentors if there were any changes to incorporate in their biographical information.

Professor Koh provided the mentors with the Web address (URL) for the class WebBoard. It was necessary for participants to register themselves on the WebBoard each semester in order to assure that only those students and mentors who registered could participate in the conferencing.

Class lectures and discussions that took place at The Dominican University provided an overview on cataloging Internet resources, starting with description. Students were expected to take what was learned in class and develop a catalog record for each of two Internet resources they chose by applying and citing Anglo American Cataloging Rules, 2nd ed. revised, Cataloging Internet Resources: A Manual and Practical Guide, and USMARC. Professor Koh made sure that the mentors understood that for most of her students, this was their first cataloging experience and their first formal catalog- 
ing course, although they had all completed one required introductory course in "Organization of Knowledge."

In order to make the mentoring of each student individually manageable, and to facilitate providing answers to student questions, Professor Koh created each of the mentor's names as separate conferences under "Mentoring by Catalogers." Students would then post drafts of the records for their selected Internet resources to the "conference" of the mentor they had chosen. These records were thus made available on the WebBoard for input and critiquing by the mentor. In addition to posting their records, students also asked questions along the way concerning problems they encountered while cataloging these resources. Mentors were instructed to respond to students on the WebBoard.

\section{MENTOR'S ROLE}

There are many challenges facing mentors who are, after all, practicing catalogers rather than educators. Mentors must make the effort to provide constructive criticism of the students' work and incorporate affirmative, positive reinforcement. Because there is no face-to-face interaction through the WebBoard, mentors need to take the time to provide feedback and well thought out responses that will properly evaluate and reinforce the strengths of their students' cataloging. It was difficult at times, for instance, to judge whether our comments were fully understood, because we lacked the obvious visual cues and had to depend on our students being brave enough to say when they did not understand us.

Too much information in a Web environment can also be problematic. We tried to be concise, use short, coherent statements and ask direct questions. Sometimes we would write several responses dealing with different concepts for the same record rather than send one complex analysis. This allowed us to create discussion threads on topics of particular interest or difficulty.

We reviewed each record carefully looking for an understanding of the process of organizing information, application of the specific rules for electronic resources and an awareness of users' searching behavior. It was a challenge at times to step back from looking for every miscoded indicator, and evaluate instead whether a student had in fact grasped fundamental principles of information science. We also provided links and citations for reference tools so that our students could learn more about a particular cataloging rule or MARC field. 


\section{THINGS TO CONSIDER}

The following illustrate some of the aspects of long distance mentoring that have had to be dealt with and resolved based on experience gained through repeated offering of the class.

\section{Technology}

Every working environment is not technologically equivalent. A perfect example was Sue Neumeister's first semester of mentoring. Students would post their catalog records as file attachments using the version of Word that came with Microsoft Office 95. The University at Buffalo Libraries where Sue worked, however, were still in the process of converting to Microsoft Office 95 and there was only one workstation in technical services that had the necessary software. Sue had to go to that workstation to view and download the attached file, save it in the earlier version of MS Word, and then take it back to her own work area. When recruiting new mentors, a message from the instructor outlining the technological requirements necessary to participate is essential.

\section{Instructor's Role}

Telling mentors ahead of time exactly what the assignment will be maximizes the learning experience for the students, and makes the mentors more effective. There were times, for example, when some students included more description in their catalog records than others, including such things as fixed field information, call numbers, and subject headings. Some students did authority work, others did not. Early in the mentoring program, some cataloged two sites, others only one. We didn't know if the students providing less information were being negligent, or if the students including more information were trying to gain extra credit. A clear understanding of the objectives and expectations at the beginning helps to avoid misunderstandings later.

At the inception of the program, during the summer of 1998, mentors were scarce and the class size was large. That first semester, some mentors had four students in the "Internet Resources Cataloging and Access Management" class. Later experience has shown that to be fair to the students, a maximum of two students for each mentor per semester would be ideal. Sometimes the course has been offered in a regular semester consisting of 14 weeks and other times it has been offered in an executive format over six weeks. In the executive format, everything seems to be intensified in a short amount of time. If you mentored more than two students in this shorter format, it was really a 
challenge, and required very quick response. By the time Kate Harcourt came on board in 2000 , the workload, while intense, was manageable.

\section{BENEFITS FOR MENTORS}

We both found that mentoring sharpened our cataloging skills as we would check and double-check the rules as part of reviewing our students' records. Mentoring also gave us an opportunity to work with electronic resources that may be unfamiliar to those of us in academia, such as community information Websites. In a few instances, we were able to help Professor Koh by calling her attention to relevant digital projects at our institutions. Using the WebBoard also gave us a glimpse of some of the challenges our public services colleagues are grappling with as they design online reference services and chat rooms.

\section{CONCLUSION}

We always had a stimulating experience when we mentored. In some cases, it was a learning experience for us as well as for the students, as we just tried to keep one step ahead of them. Distance learning mentoring has some problems, but on the whole it is a good way to get different perspectives on ways to catalog. Through contact with practicing catalogers as mentors, Professor Koh's students learned early on about cataloger's judgment. They not only learned to reinforce their position by citing rules and examples, but they also realized that there are frequently valid alternative ways to catalog the same item. The field of cataloging, especially with Internet resources, is constantly evolving and, as mentors, we need to stay current with those changes if we are to train our future colleagues properly.

Professor Koh emphasized to the mentors that the cataloging exercises done by their students represented the very first time that most of them had ever cataloged anything, and that it took a lot of courage for them to post their catalog records for us to critique. As mentors, we hoped that through positive feedback and encouragement, their apprehensiveness would fade. It was rewarding to watch students' confidence grow even in the short time we served as mentors. We only regret that we may never know how many students went on to choose careers in cataloging.

After each semester, Professor Koh extended her sincere appreciation for our generous participation and for incorporating our mentoring in our busy daily schedules. In return, we would like to thank her for providing this inno- 
vative way of teaching and giving us the opportunity to help shape tomorrow's catalogers. 